\title{
Analysis of Head Losses Consequent Section Diameter, Pipe Material and Flow Debit Using Contrast Test (Scheffe's Method) at 900 Elbow Joint
}

\author{
Am. Mufarrih ${ }^{1}$, Saut Kasdiardi Silalahi ${ }^{1}$, Irwan Setyowidodo ${ }^{1}$
}

\begin{abstract}
Piping system is needed notice on group of high population people. Water flows come out from people residend sometimes unstable when used. This anomaly can be happened because factor of section diameter, pipe material, and flow debit passed through pipes elbow. This research intends to know effect section diameter, pipe material varians, flow debit of head losses and knowing coefficient losses consequent reynold number. This research is using factorial desain orthogonal array $\mathrm{L}_{12}$ then data analysis used Analysis of Variance (ANOVA) with assistance minitab 16 software and contrast test (Scheffe's Method). The results of this experiment head losses highest value of pipe section diameter 1 inch towards $3 / 4$ inch, PVC (Poly Vinyl Cholide) pipe material, and flow debit 20 liter/minutes is $42.33 \mathrm{~mm}$. For head loses lowest value of pipe section diameter $3 / 4$ inch toward 1 inch, PE (Polyethylene) pipe material, and flow debit 10 liter/minutes is 5.33 mm, although highest coefficient losses of section diameter $3 / 4$ inch towards 1 inch, PVC (Poly Vinyl Cholide) pipe material, and flow debit 10 liter/minutes is 1.4602. ANOVA result and contrast test (Scheffe's Method) concluded section diameter, pipe material, and fluid flow debit significant effect of head losses. Based the conclusion of research, reseacher suggest that small section diameter toward big section diameter, better pipe material and low flow debit if want to reduce head losses value of piping system.
\end{abstract}

Keywords — Head losses, section diameter, pipe material, flow debit, $90^{0}$ elbow joint.

\section{INTRODUCTION}

$\mathrm{I}^{\mathrm{n}}$ n general every day we are all always associated with $\mathbf{I}_{\text {fluid almost anywhere and anytime, fluid always }}$ influence our activities in everyday life either in liquid or gas. But basically the fluid used often experience loss or unstable when flowing through the piping system. The loss is caused by friction with walls, consequent section diameter, connections, valves, bends pipe, pipe materials and other special losses [1].

In this study has the purpose of the problem to determine the effect of consuquent section diameter, Variation of pipe material, fluid flow discharge to head losses and know the coefficient of loss on elbow $90^{\circ}$ connection due to reynold number [2]. Fluid is a substance or a material in equilibrium can not withstand force or shear force. The basic properties of fluid are density, specific gravity, pressure, and viscosity [3].

The pipe material in question is the structure of the new material of the pipe which can be divided in general among others: Carbon steel, Carbon moly, Galvanees, Ferro nikel, Stainless steel, PVC (Poly Vinyl Chloride), PE (Polyethylene), and Chrome Moly. Special materials can be grouped, among others: Vibbre glass, Aluminum, wrought iron (iron without wrought), copper (copper), red brass (red brass) and others [4].

The basic equations of the fluid flow have 3 equations, among others, the continuity equation obtained from the law of conservation of mass. The continuity equation can be known by the formula [5]:

$$
\text { Flow Debit }(Q)=A_{1 . v i}=A_{2 . v 2}
$$

Where $A$ is cross-sectional area $\left(\mathrm{m}^{2}\right)$ and $\mathrm{v}$ is flow velocity $(\mathrm{m} / \mathrm{s})$. The bernoulli equation is the result of fluid motion causing or generating energy, especially mechanical energy that is as a result of fluid velocity. The form of energy formula can be known by the formula [6]:

$$
\text { Energy }(E)=v^{2} / 2 g+P / \rho g+z
$$

Where $\mathrm{P}$ is pressure on liquid $\left(\mathrm{N} / \mathrm{m}^{2}\right), \rho$ is density $\left(\mathrm{kg} / \mathrm{s}^{2}\right)$, $\mathrm{g}$ is gravity $\left(9.81 \mathrm{~m} / \mathrm{s}^{2}\right)$ and $\mathrm{z}$ is elevation $(\mathrm{m})$. The momentum equation is something that is proportional to the force acting on the object.

The move fluids can be classified into several categories of laminar flow and turbulent flow. The difference between laminar flow and turbulence was first experimentally exposed by Osborne Reynolds in 1883 [6].

\footnotetext{
${ }^{1}$ Am. Mufarrih, Saut Kasdiardi Silalahi and Irwan Setyowidodo are with Department of Mechanical Engineering, Faculty of Engineering, Universitas Nusantara PGRI Kediri, Kediri 64112, Indonesia. E-mail: sautkasdiardisilalahi17@gmail.com; irwan.setyowidodo@gmail.com
} 


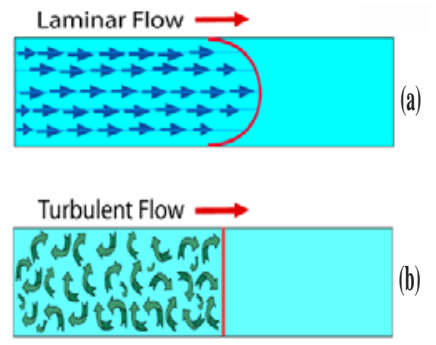

Figure 1. Fluid Flow (a) Laminar flow and (b) turbulent flow.

The minor loss is the head loss caused by the friction occurring in the valves, the connection of the tees, the bend connections, and consequent section diameter. Finding the loss coefficient or the value of " $k$ " can use the following equation [5]:

Actual Coefficient of $\operatorname{Loss}\left(k_{k b-a c t}\right)=(\Delta h \times 2 \mathrm{~g}) / v^{2}$

Where $\Delta \mathrm{h}$ is actual head loss $(\mathrm{m})$. Basically this energy loss can be known by comparing several factors by way of calculation according to the previous equation.

The Scheffe method is one of the contrast test methods used to compare all data that is likely to be contrasted or prominent among treatment averages [7]. The contrast set can use the standard error as follows:

$$
\text { Standard error }\left(S_{C u}\right)=\sqrt{M S_{E} \sum_{i=1}^{a}\left(C_{1_{u}}^{2} / n_{i}\right)}
$$

Where $\mathrm{MS}_{\mathrm{E}}$ is Mean squares of error, $C_{1_{u}}^{2}$ is Contrast data set " $u$ " and $n$ is Number of observations. While the critical value to be compared with $\mathrm{Cu}$ can be determined through the following formulation [7]:

$$
\text { Critical Value }\left(S_{\alpha \cdot u}\right)=S_{C_{u}} \sqrt{(\alpha-1) F_{\alpha_{a-1 N-a}}}
$$

Where $\mathrm{Sc}_{\mathrm{u}}$ is Standard error for contrast data set " $\mathrm{u}$ ", $a-$ 1 is degree of freedom and $F_{\alpha_{a-1 N-a}}$ is $F_{\text {tabel. }}$ If the value is $\left|C_{u}\right|>\left(S_{\alpha \cdot u}\right)$ then the average of the data set differs significantly or which may be referred to as contrast [7].

\section{METHOD}

Variables are everything that will be the object of research observation, there are 3 variables in the study. First independent variable which is variable which can be controlled in this research for independent variable section diameter 1 inch toward $3 / 4$ inch and $3 / 4$ inch toward 1 inch, PVC pipe material (Poly Vinly Chloride) and pipe PE (Polyethylene), and fluid flow discharge 10, 15, and 20 liter/min. The dependent variable or the response are the variables that can be known after conducting the experiment in this study for the independent variable is the head losses. Last is the control variable is the variable that contans, in the research for the control variable is the water pump.

The experimental design of this research is preceded by the setting of factors in which there needs to be a matrix selection depending on the number of control variables and levels in the experiment. The experimental design in this study contained 12 treatments or can be called the factorial design orthogonal array $L_{12}$ with 3 replication (repetition), This replication to reduce for noise factor. Then for the factor and level of research used this research can be seen in table 1 that explain some factors and level in independent variable.

TABLE 1.

INDEPENDENT VARIABLE AND RESEARCH LEVEL.

\begin{tabular}{ccllll}
\hline \hline Independent Variable & Level & \multicolumn{3}{c}{ Variable Value } \\
\hline Diameter & 2 & 1 inch & 3/4 Inch & - \\
Pipe Material & 2 & PVC Pipe & PE Pipe & - \\
Flow Debit & 3 & $10 \mathrm{l} / \mathrm{min}$ & $15 \mathrm{l} / \mathrm{min}$ & $20 \mathrm{l} / \mathrm{min}$ \\
\hline \hline
\end{tabular}

The experimental matrix or experimental data can be determined by using 3 replications to obtain maximum results for it there are 36 research results Head Losses. The research scheme of Head Losses on elbow $90^{\circ}$ joint can be seen in figure 2.

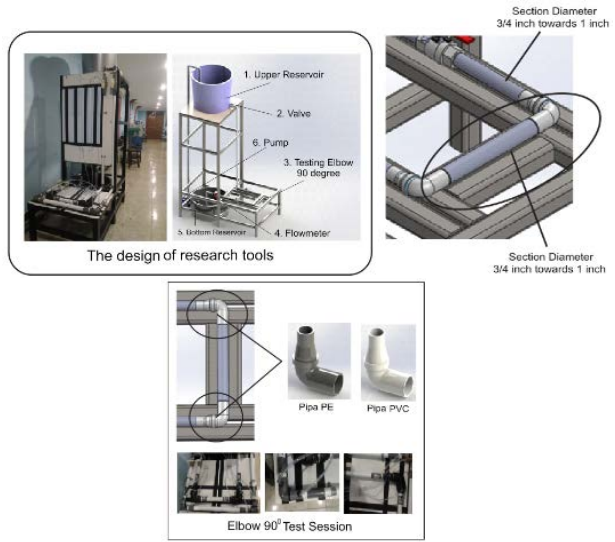

Figure 2. Research installation Schematic.

Test session changes the pipe elbow $90^{\circ}$ with a diameter of 1 inch toward 3/4 inch and 3/4 inch toward 1 inch the replacement of the pipe material and the procedure of research can be viewed figure 3 this below.
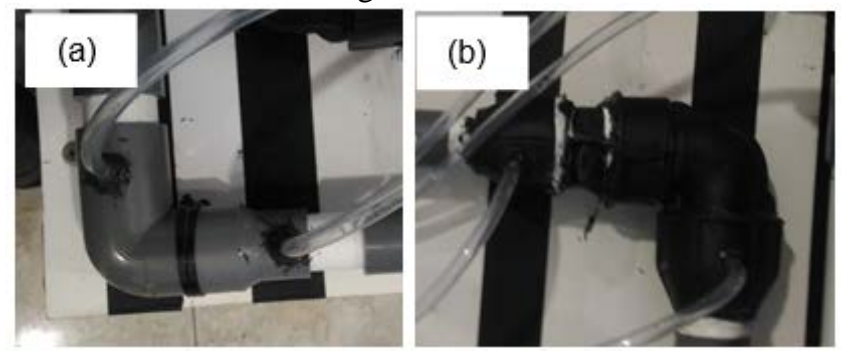

Figure 3. Elbow $90^{\circ}$ Test Session with (a) PVC Pipe and (b) PE Pipe.

Then mounted manometer gauges that will be observed and taken data periodically. Implementation phase of the research begins with a study of literature to obtain information data, and theory related to the object of research. Then followed the procedure of research (1) preparation of research tool, (2) Research stage, (3) then stage of data cap losses on manometer.

the research results obtained height values $\left(h_{1}, h_{2}, h_{3}\right.$, and $\mathrm{h}_{4}$ ) on the manometer. The results obtained can be used as the basis for the calculation of velocity (v), loss coefficient, Reynold number and Head Losses $\left(\mathrm{h}_{\mathrm{L}}\right)$, in accordance with predetermined equations.

Then for data analysis technique used in this research is Statistical Analysis of Variance (ANOVA). ANOVA test requirement is analyzed data must first be tested assumption of IIND (Identical, Independent, and Normal Distribution). ANOVA using a significant level of 0.05 or 
$5 \%$ means the accepted hypothesis of $95 \%$ for software used is Minitab 16, then tested again with a further test contrast Scheffe method to determine the contrast or not every data tested.

\section{RESULT AND ANALYSIS}

The value of head losses that have been measured on the manometer of various variations can be seen in Figure 4.

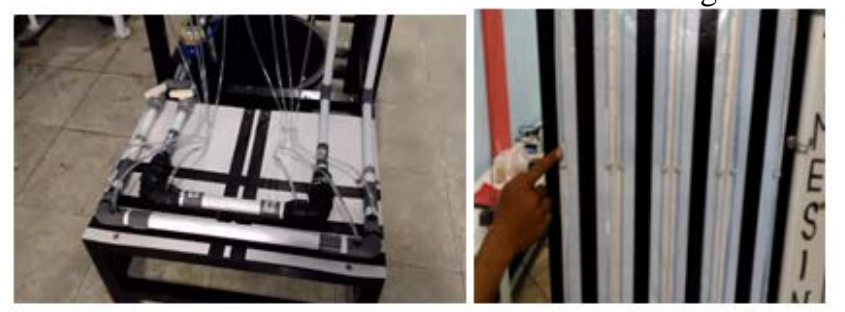

Figure 4. Data Retrieval

Table 2 is the result of data collection from the manometer gauge for Head Losses test with 3 replications. The result of head losses is the result that we will analyze with ANOVA so it will know some influence to the variables freely varied. In addition to looking for the research losses it also looks for fluid flow whether it includes Laminar or Turbulent flows and the loss coefficient of the head losses result.

TABLE 2.

Data Collection Testing Head Losses.

\begin{tabular}{|c|c|c|c|c|c|c|}
\hline \multirow{3}{*}{$\begin{array}{c}\text { Pipe } \\
\text { Material }\end{array}$} & \multirow{3}{*}{$\begin{array}{l}\text { Flow } \\
\text { Debit }\end{array}$} & \multirow{3}{*}{ Replication } & \multicolumn{4}{|c|}{ Data Retrieval (mm) } \\
\hline & & & \multicolumn{2}{|c|}{$\begin{array}{l}\text { Diameter } \\
1 \text { inch }\end{array}$} & \multicolumn{2}{|c|}{$\begin{array}{c}\text { Diameter } \\
3 / 4 \text { inch }\end{array}$} \\
\hline & & & $\mathbf{h}_{1}$ & $\mathbf{h}_{2}$ & $\mathbf{h}_{3}$ & $\mathbf{h}_{4}$ \\
\hline \multirow{9}{*}{ PVC pipe } & \multirow{3}{*}{$10 \mathrm{l} / \mathrm{min}$} & 1 & 295 & 304 & 299 & 279 \\
\hline & & 2 & 291 & 298 & 293 & 275 \\
\hline & & 3 & 288 & 294 & 289 & 272 \\
\hline & \multirow{3}{*}{$15 \mathrm{l} / \mathrm{min}$} & 1 & 224 & 239 & 231 & 198 \\
\hline & & 2 & 220 & 234 & 226 & 194 \\
\hline & & 3 & 217 & 229 & 220 & 190 \\
\hline & \multirow{3}{*}{$20 \mathrm{l} / \mathrm{min}$} & 1 & 82 & 106 & 104 & 60 \\
\hline & & 2 & 78 & 100 & 98 & 56 \\
\hline & & 3 & 75 & 95 & 95 & 54 \\
\hline \multirow{9}{*}{ PE pipe } & \multirow{3}{*}{$10 \mathrm{l} / \mathrm{min}$} & 1 & 81 & 88 & 86 & 71 \\
\hline & & 2 & 78 & 83 & 82 & 69 \\
\hline & & 3 & 76 & 80 & 76 & 64 \\
\hline & \multirow{3}{*}{$15 \mathrm{l} / \mathrm{min}$} & 1 & 44 & 57 & 53 & 28 \\
\hline & & 2 & 42 & 53 & 48 & 25 \\
\hline & & 3 & 41 & 50 & 44 & 23 \\
\hline & \multirow{3}{*}{$20 \mathrm{l} / \mathrm{min}$} & 1 & 21 & 40 & 29 & -12 \\
\hline & & 2 & 18 & 35 & 26 & -10 \\
\hline & & 3 & 15 & 30 & 23 & -9 \\
\hline
\end{tabular}

After the data from the water manometer is obtained, then for the next we can determine the head losses and for determine the type of flow can be done by measuring the temperature or temperature of water, so that the temperature of water obtained for $26{ }^{\circ} \mathrm{C}$ then according to the table of water thickness properties (kinematic viscosity) for $v=$ $0.8832 \times 10-6 \mathrm{~m}^{2} / \mathrm{s}$. Table result of average data of research of head losses we can see table 2 .

TABLE 3.

DATA ON RESEARCH HEAD LOSSES.

\begin{tabular}{llcc}
\hline \hline $\begin{array}{c}\text { Section } \\
\text { Diameter }\end{array}$ & Pipe Material & $\begin{array}{c}\text { Flow } \\
\text { Debit }\end{array}$ & $\begin{array}{c}\text { Head Losses } \\
\left.\mathbf{( h}_{\mathbf{L}}\right)\end{array}$ \\
\hline $\begin{array}{l}\text { Section } \\
\text { diameter } 3 / 4\end{array}$ & PVC pipe (Poly & $10 \mathrm{l} / \mathrm{min}$ & $7.33 \mathrm{~mm}$ \\
\hline
\end{tabular}

\begin{tabular}{|c|c|c|c|}
\hline \multirow{4}{*}{$\begin{array}{l}\text { toward } \\
\text { inch }\end{array}$} & \multirow{4}{*}{$\begin{array}{l}\text { PE pipe } \\
\text { (Polyethylene) }\end{array}$} & $20 \mathrm{l} / \mathrm{min}$ & $22 \mathrm{~mm}$ \\
\hline & & $10 \mathrm{l} / \mathrm{min}$ & $5.33 \mathrm{~mm}$ \\
\hline & & $15 \mathrm{l} / \mathrm{min}$ & $11 \mathrm{~mm}$ \\
\hline & & $20 \mathrm{l} / \mathrm{min}$ & $17 \mathrm{~mm}$ \\
\hline \multirow{6}{*}{$\begin{array}{l}\text { Section } \\
\text { diameter } 1 \\
\text { toward } 3 / 4 \\
\text { inch }\end{array}$} & \multirow{3}{*}{$\begin{array}{l}\text { PVC pipe (Poly } \\
\text { Vinyl Chloride) }\end{array}$} & $10 \mathrm{l} / \mathrm{min}$ & $18.33 \mathrm{~mm}$ \\
\hline & & $15 \mathrm{l} / \mathrm{min}$ & $31.66 \mathrm{~mm}$ \\
\hline & & $20 \mathrm{l} / \mathrm{min}$ & $42.33 \mathrm{~mm}$ \\
\hline & \multirow{3}{*}{$\begin{array}{l}\text { PE pipe } \\
\text { (Polyethylene) }\end{array}$} & $10 \mathrm{l} / \mathrm{min}$ & $13.33 \mathrm{~mm}$ \\
\hline & & $15 \mathrm{l} / \mathrm{min}$ & $23 \mathrm{~mm}$ \\
\hline & & $20 \mathrm{l} / \mathrm{min}$ & $36 \mathrm{~mm}$ \\
\hline
\end{tabular}

In table 3 Shows that the average head losses generated section diameter 1 inch toward $3 / 4$ inch higher as well as the increasing flow of head losses flow produced is also higher, while for PVC pipe material is higher than the PE Pipe.

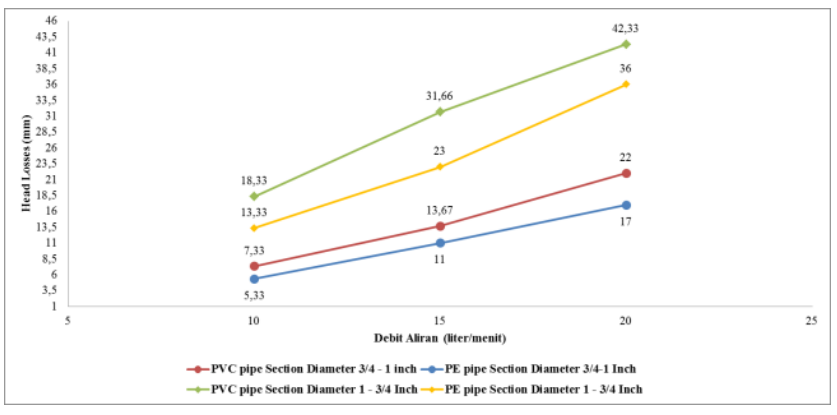

Figure 5. Graph of Average Head Losses

The relationship value of loss coefficient and reynold number we can know according to table 4.

TABLE 4.

DATA VALUE OF LOSSES COEFFICIENT AND REYNOLDS NUMBER.

\begin{tabular}{|c|c|c|c|c|}
\hline $\begin{array}{c}\text { Section } \\
\text { Diameter }\end{array}$ & $\begin{array}{c}\text { Pipe } \\
\text { Material }\end{array}$ & $\begin{array}{l}\text { Flow } \\
\text { Debit }\end{array}$ & $\begin{array}{l}\text { Reynold } \\
\text { Number }\end{array}$ & $\begin{array}{c}\text { Losses } \\
\text { Coefficient }\end{array}$ \\
\hline \multirow{6}{*}{$\begin{array}{l}\text { Section } \\
\text { diameter } \\
3 / 4 \text { toward } \\
1 \text { inch }\end{array}$} & \multirow{3}{*}{ PVC pipe } & $10 \mathrm{l} / \mathrm{min}$ & 12325.3 & 1.46026 \\
\hline & & $15 \mathrm{l} / \mathrm{min}$ & 19258.4 & 1.11472 \\
\hline & & $20 \mathrm{l} / \mathrm{min}$ & 25412 & 1.02987 \\
\hline & \multirow{3}{*}{ PE pipe } & 10 l/min & 12087.6 & 1.10418 \\
\hline & & $15 \mathrm{l} / \mathrm{min}$ & 18887.1 & 0.93277 \\
\hline & & 20 l/min & 24930.8 & 0.82733 \\
\hline \multirow{6}{*}{$\begin{array}{l}\text { Section } \\
\text { diameter } 1 \\
\text { toward } 3 / 4 \\
\text { inch }\end{array}$} & \multirow{3}{*}{ PVC pipe } & 10 l/min & 9022.5 & 1.10046 \\
\hline & & $15 \mathrm{l} / \mathrm{min}$ & 14097.7 & 0.77866 \\
\hline & & $20 \mathrm{l} / \mathrm{min}$ & 18608.8 & 0.59733 \\
\hline & \multirow{3}{*}{ PE pipe } & $10 \mathrm{l} / \mathrm{min}$ & 8953.4 & 0.85855 \\
\hline & & $15 \mathrm{l} / \mathrm{min}$ & 13989.8 & 0.6066 \\
\hline & & $20 \mathrm{l} / \mathrm{min}$ & 18466.6 & 0.54996 \\
\hline
\end{tabular}

Make it easier to know the relationship see the graph of the relationship value of the coefficient of loss and reynold number in figure 6. 


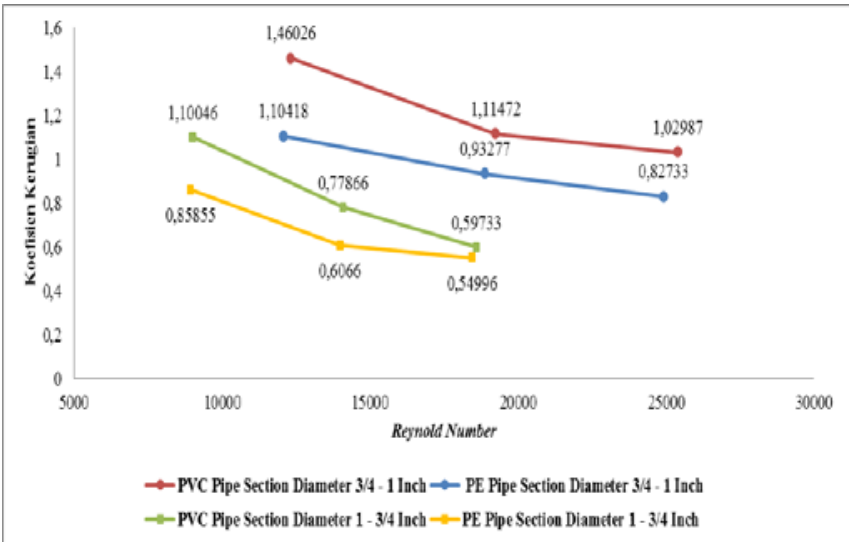

Figure 6. Graph of Average Relationship Value of Coefficient of Loss

From figure 6 We can see that the section diameter $3 / 4$ toward 1 inch has a greater loss coefficient, it appears that the PE pipe has a lower loss coefficient than the PVC pipe as well as the fluid flow flow change causing the increasing flow velocity and the reynold number. Seen from table 4 . can be ascertained the result of reynold number exceeds 4000 so that can be interpreted all turbulent flow.

\section{A. Data Analysis}

The procedure of data analysis, need to be tested first with the assumption of IIDN (Identical, Independent, and Normal Distribution). The first residual normality test is performed using Anderson-Darling Test contained in the minitab 16 program.

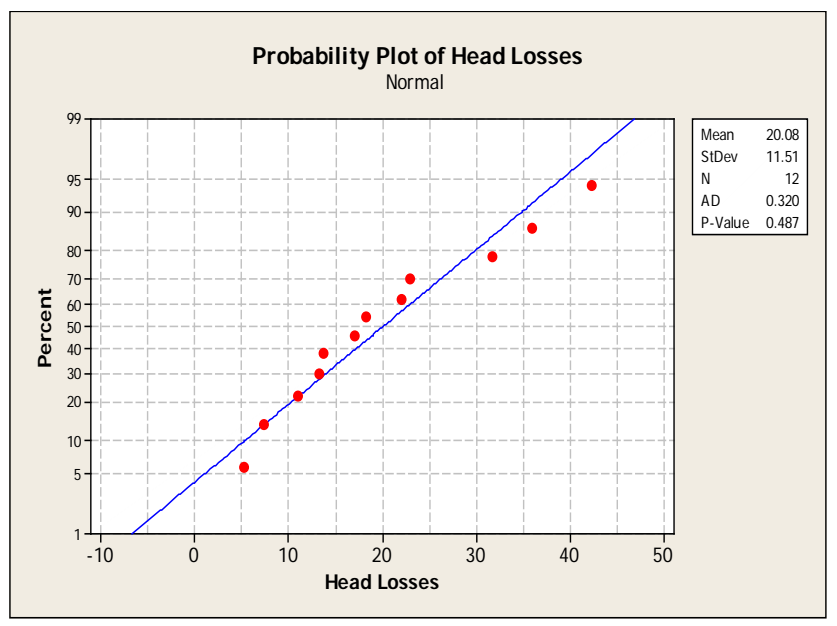

Figure 7. Plot of normal distribution test on head losses response

Normal test explains $\mathrm{H}_{0}$ is rejected if $\mathrm{p}$-value is smaller than $\alpha=0.05$. figure 7. Showed that with Anderson-Darling test obtained P-Value of 0.487 which means greater than $\alpha$ $=0.05$. Therefore, it can be concluded that $\mathrm{H}_{0}$ is a normally distributed residual.

Then the identical test to find out whether the research data produced identical or not.

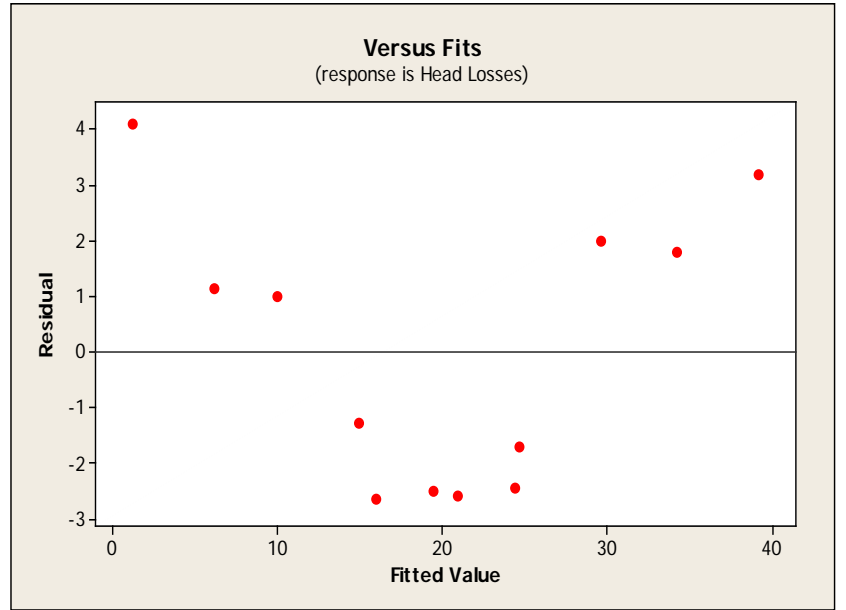

Figure 8. Plot residual head losses versus fitted values

Figure 8 Shows that the largest residual is randomly around the price of minus two and does not form a particular pattern. Thus identical residual assumptions are met. Last independent testing, this research is done by using Auto Corelation Function (ACF) which is in program of minitab 16.

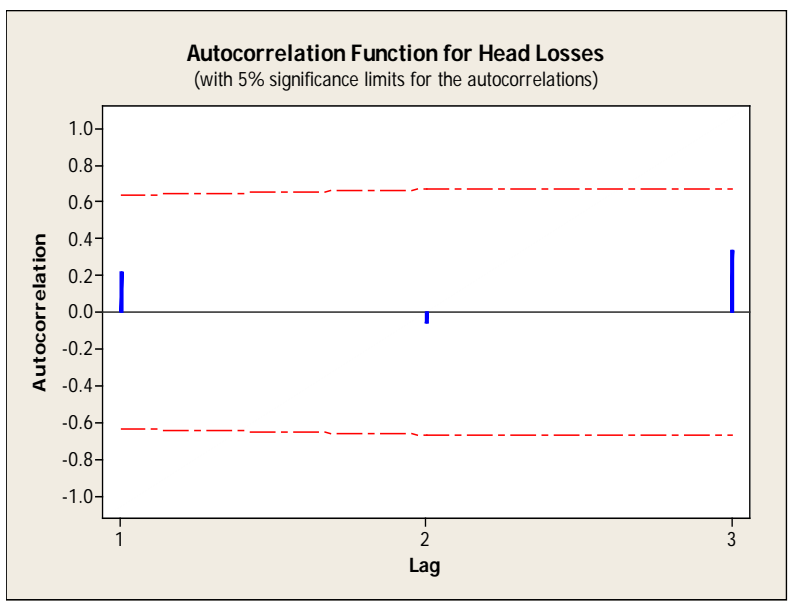

Figure 9. ACF plot in head losses response

Based on the ACF plot shown in figure 9. There is no AFC value on each lag that exits the interval limit. This proves that there is no inter-residual collation meaning independent.

\section{B. Data Analysis Results}

Data analysis using analysis of variance (ANOVA), Analysis of Variance (ANOVA) is used to determine the effect of process variables that have a significant influence on head losses. From the analysis results obtained table 5.

TABLE 5.

ANALYSIS OF VARIANS FOR HEAD LOSSES, USING ADJUSTED SS FOR

TESTS.

\begin{tabular}{lcccccc}
\hline \hline \multicolumn{1}{c}{ Source } & DF & Seq SS & Adj SS & Adj MS & F & P \\
\hline Diameter & 1 & 650.04 & 650.04 & 650.04 & 68.36 & 0.000 \\
Pipe Material & 1 & 73.31 & 73.31 & 73.31 & 7.71 & 0.027 \\
Flow Debit & 2 & 666.68 & 666.68 & 333.34 & 35.05 & 0.000 \\
Error & 7 & 66.56 & 66.56 & 9.51 & & \\
Total & 11 & 1456.59 & & & & \\
\hline \multicolumn{7}{c}{$\mathrm{S}=3.08369$ R-Sq $=95.43 \%$ R-Sq(adj) $=92.82 \%$} \\
\hline \hline
\end{tabular}


The percentage of contribution contribution of each research factor (independent variable) to head losses is as follows.

TABLE 6.

PERSENTSE CONTRIBUTION.

\begin{tabular}{lccccc}
\hline \hline $\begin{array}{c}\text { Independen } \\
\text { Variable }\end{array}$ & DF & Seq SS & Adj MS & SS' & \% Contribution \\
\hline $\begin{array}{l}\text { Section } \\
\text { Diameter }\end{array}$ & 1 & 650.04 & 650.04 & 640.53 & 44.63 \\
Pipe Material & 1 & 73.31 & 73.31 & 63.8 & 5.03 \\
Flow Debit & 2 & 666.68 & 35.05 & 647.66 & 45.77 \\
\hline Error & 7 & 66.56 & 9.51 & & 4.57 \\
Total & 11 & 1456.59 & & & 100.00 \\
\hline \hline
\end{tabular}

Table 6 is the percentage of contribution used to find out how percent of independent variables affect the dependent variable.

\section{Hypothesis Testing}

Hypothesis testing to draw conclusions according to data analysis can use how to compare the value of generated from analysis of variance and $\mathrm{F}_{\text {tabel }}$ from distribution table F, (significant) 0.05 .

Independent Variable Section Diameter. Conclusion: $\mathrm{F}_{\text {hitung }}=68.36>\mathrm{F}_{(0.05 ; 2,33)}=3.28$, then $\mathrm{H}_{0}$ is rejected, meaning there is effect section diameter on head losses. Independent Variable Pipe Material. Conclusion: $\mathrm{F}_{\text {hitung }}=$ $7.71>\mathrm{F}_{(0.05 ; 2,33)}=3.28$, then $\mathrm{H}_{0}$ is rejected, meaning there is effect pipe material on head losses. Independent Variable Flow Debit. Conclusion: $\mathrm{F}_{\text {hitung }}=35.05>\mathrm{F}_{(0.05 ; 2,33)}=3.28$, then $\mathrm{H}_{0}$ is rejected, meaning there is effect flow debit on head losses.

Testing the hypothesis in a second way based on P-Value compared with a significant level of $5 \%(\alpha=0.05)$, if the PValue produced by the variant analysis is smaller than the significance level of $5 \%(\alpha=0,05)$ Then the independent variable may have an effect on the result of head losses in the research. Can be seen from table comparison of P-Value and significant value $(\alpha=0.05)$.

TABLE 7.

COMPARISON OF P-VALUE AND $\alpha$

\begin{tabular}{lllc}
\hline \hline Independent Variable & $\boldsymbol{P}$-Value & $\boldsymbol{\alpha}$ \\
\hline Section Diameter & 0.000 & $<$ & 0,05 \\
Pipe Material & 0.027 & $<0,05$ \\
Flow Debit & 0.000 & $<0,05$ \\
\hline \hline
\end{tabular}

Based on the hypothesis test comparing the value of $F_{\text {hitung }}$ resulting from the analysis of variance and $\mathrm{F}_{\text {tabel }}$ from the distribution table F, $\alpha$ (significant) 0.05 and based on PValue compared with the 5\% significance level $(\alpha=0.05)$, explains or concludes that independent variables have significant influence on head losses both section diameters, pipe materials and fluid flow discharge with a confidence level of $95 \%$. So to more easily conclude hypothesis for each independent variable to head losses shown in table 8.

TABLE 8.

CONCLUSION INFLUENCE OF FREE VARIABLE TO HEAD LOSSES

\begin{tabular}{lc}
\hline \hline Independent Variable & Conclusion Hypothesis \\
\hline Section Diameter & Take effect \\
\hline
\end{tabular}

\begin{tabular}{ll}
\hline Pipe Material & Take effect \\
Flow Debit & Take effect
\end{tabular}

The effect of these three variables can be seen clearly through the main effect plot image for head losses obtained from the ANOVA test on Minitab 16 Software as follows.

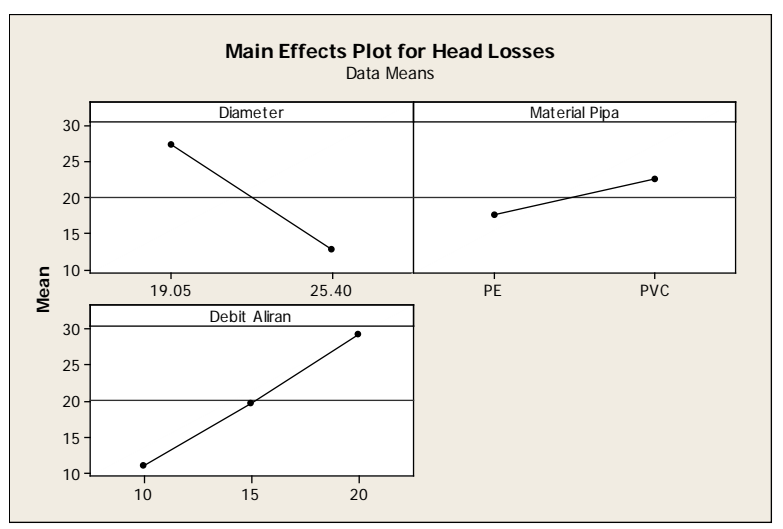

Figure 10. Plot effect given free variable to Head Losses

Figure 10, it can be explained that the cross-sectional diameter from large to small makes the higher head losses produced by having a statistically significant effect. PVC pipe material has larger head losses than PE pipe so it has a significant effect. The flow discharge increases or increases the amount or height of the resulting losses resulting in significant influence.

\section{Contrast Testing (Scheffe Method)}

Scheffe method is used by researchers to compare data of research results so that known data that is contrast or data that has the most significant influence. Table 9 is the result of contrast testing by comparing data head losses diameter $3 / 4$ toward 1 inch and 1 towards $3 / 4$ inch.

TABLE 9.

CONTRAST TESTING FOR DATA COMPARISON SECTION DIAMETER

\begin{tabular}{ccccc}
\hline \hline & $|C|$ & & $\mathbf{S}_{\mathbf{0}, 05}$ & Result \\
\hline$\mu_{1}-\mu_{4}$ & 2.00 & $<$ & 2.02 & No Contrast \\
$\mu_{2}-\mu_{5}$ & 2.67 & $>$ & 2.02 & Contrast \\
$\mu_{3}-\mu_{6}$ & 5.00 & $>2.02$ & Contrast \\
$\mu_{7}-\mu_{10}$ & 5.00 & $>2.02$ & Contrast \\
$\mu_{8}-\mu_{11}$ & 8.66 & $>2.02$ & Contrast \\
$\mu_{9}-\mu_{12}$ & 6.33 & $>$ & 2.02 & Contrast \\
\hline \hline
\end{tabular}

Contrast test results in table 9 contrast head loss test results comparison diameter 1 inch toward 3/4 inch $\left(\mu_{7}, \mu_{8}\right.$, $\left.\mu_{9}, \mu_{10}, \mu_{11}, \mu_{12}\right)$ has a higher contrast test result compared to the average data of the losses diameter $3 / 4$ inch toward 1 inch $\left(\mu_{1}, \mu_{2}, \mu_{3}, \mu_{4}, \mu_{5}, \mu_{6}\right)$.

Then compare the mean head losses of diameter section 1 inch toward $3 / 4$ inch with PVC pipe and PE pipe, so here is the contrast test result compare the mean head losses of of diameter section 1 inch toward 3/4 inch with PVC and PE pipe.

TABLE 10.

CONTRAST TESTING FOR DATA COMPARISON PVC AND PE PIPES

\begin{tabular}{ccccc}
\hline \hline$\Gamma$ & $|C|$ & & $\mathbf{S}_{0,05}$ & Result \\
\hline$\mu_{7}-\mu_{8}$ & 13.33 & $>$ & 2.02 & Contrast \\
$\mu_{7}-\mu_{9}$ & 24 & $>$ & 2.02 & Contrast \\
\hline
\end{tabular}




\begin{tabular}{cllll}
\hline$\mu_{8}-\mu_{9}$ & 10.67 & $>$ & 2.02 & Contrast \\
$\mu_{10}-\mu_{11}$ & 9.67 & $>$ & 2.02 & Contrast \\
$\mu_{10}-\mu_{12}$ & 22.67 & $>2.02$ & Contrast \\
$\mu_{11}-\mu_{12}$ & 13 & $>2.02$ & Contrast \\
\hline \hline
\end{tabular}

Based on the results of contrast testing in table 10 explains that the value of head losses for PVC pipe material $\left(\mu_{7}, \mu_{8}\right.$, and $\left.\mu_{9}\right)$ have a more contrast test or higher than PE pipe material $\left(\mu_{10}, \mu_{11}\right.$, and $\left.\mu_{12}\right)$. After contrast test for comparison of pipe material variation then for flow rate can be compared in table 11.

TABLE 11.

CONTRAST TESTING FOR DATA COMPARISON VARIATION OF FLOW DEBIT

\begin{tabular}{cllll}
\hline \hline \multicolumn{1}{c}{$\Gamma$} & \multicolumn{1}{c}{$|C|$} & & $\mathbf{S}_{\mathbf{0}, \mathbf{0 5}}$ & Result \\
\hline$\mu_{1}-\mu_{7}$ & 11 & $>$ & 2.02 & Contrast \\
$\mu_{2}-\mu_{8}$ & 17.66 & $>$ & 2.02 & Contrast \\
$\mu_{3}-\mu_{9}$ & 20.33 & $>$ & 2.02 & Contrast \\
$\mu_{4}-\mu_{10}$ & 8 & $>$ & 2.02 & Contrast \\
$\mu_{5}-\mu_{11}$ & 12 & $>$ & 2.02 & Contrast \\
$\mu_{6}-\mu_{12}$ & 19 & $>$ & 2.02 & Contrast \\
\hline \hline
\end{tabular}

The result of contrast test in table 11 explains that data $\mu_{3}$ and $\mu_{9}$, where for flow debit which produces the highest contrast test at 20 liter/min flow debit while for contrast test results table 11 data $\mu_{4}$ and $\mu_{10}$ is the lowest contrast test compared to other data which is at 10 liter/min flow debit. The value of head losses in diameter section 1 toward 3/4 inch with PVC pipe material and 20 liter/min flow debit variation has a combination of more contrast test than other combinations. However, for non-contrast combination results or opposite of contrast test, there is a diameter section $3 / 4$ inch toward 1 inch with $\mathrm{PE}$ material pipe variation and 10 liter/min flow debit.

\section{E. Discussion}

Some combinations are capable of producing optimal head losses. Result of head losses with section diameter 1 inch toward $3 / 4$ inch, PVC pipe material variation at 20 liter/min flow debit has higher or more contrast factor and The result of the lowest losses head value on a combination of section diameter $3 / 4$ inch toward 1-inch variation of $\mathrm{PE}$ pipe material material flowing at 10 liter/min flow debit.

Where the influence diameter section 1 inch toward 3/4 inch capable of producing the highest head losses. According to Bernoulli's "Handbook Fluid Mechanics" theory when liquid flows through a large diameter section to a small diameter section, the liquid pressure at larger diamater section is greater than the pressure of the liquid at a small diameter section [5].

PVC pipes have high head losses compared to PE pipe. Because PE pipe construction is better or finer than PVC pipe. This is research by Brickstand. B which explains the pipe surface roughness can affect the flow debit [4].

The greater the flow debit head losses are also increasing. The highest head losses are at 20 liters/min fluid flow debit. According to research Turian. R. M "Flow of Concentrated Non-Newtonian Slurries: 2. Friction Losses in Bends, Fittings, Valves and Venturi Meters" the greater the flow debit then the flow of flow is also increasing [2].
The largest loss coefficient on the diameter section $3 / 4$ inch toward 1 inch and the 10 liter/min flow debit for the 1.46026 PVC pipe and PE pipe of 1.10418 with each reynold number for the PVC pipe of 12325.3 and for PE pipe of 12087.6 , according to the corresponding reynold number calculation results include turbulent flow.

\section{CONCLUSION}

Data reconciliation is an efective method used to reduce the impact that arise when measurement error is occured. Based on the result of data reconciliation, balance condition can be reached by satisfying the mass and energy balance as a constrain. It can generate reliable estimating data on data reconciliation. Reliable estimating data has a maximum tolerance for temperature and mass flow rate that is $1^{\circ}$ and $5 \%$. Those maximum tolerance can generate small error. It can be seen by perform a calculation that uses sum square error on five variable reconciliation in each component of heat exchanger. In this case, PSO algorithm as a nondeterministic optimization method is capable to generate reliable data and minimizing error by satisfying mass and energy balance as constraint.

Based on the result of data reconciliation, the value of standard deviation for measurement data is different to the value of standard deviation for the result of data reconciliation. It this case, data reconciliation can improve data reliability on five variable reconciliation efficienly that following normal distribution. Based on this differences, we know that there is random error on the measurement data in PLTGU Gresik. Random error can be arise for several reason: fluctuation in power supply, transmission network, noise conversion signal, and others.

There is not gross error on the measurement data in PLTGU Gresik. It can be confirmed from the value of critical based on chi square distribution that is smaller than the criterion value based on chi square table $\left(\gamma_{R} \geq x^{2}{ }_{1-5 \%, 4}\right)$. Because there is not gross error in the measurement, so that the instrument in PLTGU Gresik have a good performance and can generate optimal eficiency with consider constrain, that is mass and energy balance.

\section{REFERENCES}

[1] A. R. D. Thorley, "Pressure Transients in Hydraulic Pipelines," $J$. Basic Eng., vol. 91, no. 3, p. 453, Sep. 1969.

[2] R. M. Turian, T. W. Ma, F. L. G. Hsu, M. J. Sung, and G. W. Plackmann, "Flow of concentrated non-Newtonian slurries. 2. Friction losses in bends, fittings, valves and Venturi meters," Int. J. Multiph. Flow, vol. 24, no. 2, pp. 243-269, Mar. 1998.

[3] T. Morimune, N. Hirayama, and T. Maeda, "Study of ComPressible High Speed Gas Flow in Piping System: 1st Report, Piping Systems with Bends or Elbows,” Bull. JSME, vol. 23, no. 186, pp. 1997-2004, 1980.

[4] B. Brickstad and B. L. Josefson, "A parametric study of residual stresses in multi-pass butt-welded stainless steel pipes," Int. J. Press. Vessel. Pip., vol. 75, no. 1, pp. 11-25, Jan. 1998.

[5] F. M. White, Handbook Fluid Mechanics. Boston: McGraw-Hill, 1998.

[6] V. L. (Victor L. Streeter and E. B. Wylie, Fluid mechanics. New York: McGraw-Hill, 1975.

[7] D. C. Montgomery, Design and analysis of experiments. New York: John Wiley \& Sons, 2001. 